\title{
The Experience of Relatives of Nursing Home Residents with COVID-19: A Qualitative Study
}

\author{
Signe Tretteteig (1D) \\ Siren Eriksen $\mathbb{D}^{1,2}$ \\ Adelheid Hummelvold \\ Hillestad (D) ${ }^{2}$ \\ Signe Gunn Julnes ${ }^{3}$ \\ BjÃ,rn Lichtwarck ${ }^{4}$ \\ Anita Nilsen ${ }^{3}$ \\ Anne Marie Mork Rokstad (D) $)^{1,3}$ \\ 'Norwegian National Advisory Unit on \\ Ageing and Health, Vestfold Hospital Trust, \\ Tønsberg, Norway; ${ }^{2}$ Lovisenberg Diaconal \\ University College, Department of Bachelor \\ Education, Oslo, Norway; ${ }^{3}$ Faculty of Health \\ Sciences and Social Care, Molde University \\ College, Molde, Norway; ${ }^{4}$ The Research \\ Centre for Age-Related Functional Decline \\ and Disease, Innlandet Hospital Trust, \\ Ottestad, Norway
}

\begin{abstract}
Background: The coronavirus disease 2019 (COVID-19) pandemic had significant consequences for relatives' opportunities to communicate with and offer care to seriously ill and dying nursing home residents with COVID-19. Residents in nursing homes were urged to protect themselves through social distancing, and visits have been permanently regulated and limited. These restrictions have been challenging, and the limitations have raised many questions and led to difficult choices. The aim of this study was to explore the experiences of relatives of nursing home residents with COVID-19. We investigated the following two research questions: How did relatives of COVID-19 patients in Norwegian nursing homes experience the situation and how did the physical distancing and precepts of infection control affect the relationship between the long-term residents and the relatives?.
\end{abstract}

Methods: The study has a qualitative explorative design with a phenomenological-hermeneutic approach, with individual in-depth interviews used for data collection. The study included ten relatives of nursing home residents with COVID-19.

Results: Three main perspectives were identified from the participants' experiences: (1) the difficult choices; (2) maintaining the relationship; and (3) experiencing support. The relatives experienced ethical dilemmas when weighing the risk of getting COVID-19 if they visited the patient versus the consequences of not visiting their loved one. In this situation, they needed good information and support from health care professionals.

Conclusion: To enable relatives of COVID-19 patients to make choices in line with their goals and intrinsic motivations, it is important that staff members possess competence in infection control, updated knowledge about the residents' situations, and the skills to facilitate a safe and confident dialogue. Trust in the care staff and a feeling of safety are essential for relatives in a stressful situation with difficult choices, while a lack of confidence, routines, and/or dialogue might increase relatives' feelings of insecurity and stress and make their caring role difficult.

Keywords: nursing home, COVID-19, residents, relatives, difficult choices, relationship

\section{Introduction}

One of the main strategies of limiting the spread of coronavirus disease 2019 (COVID-19) is social distancing. In Norway, like other countries, society locked down for long periods starting in March 2020. ${ }^{1}$ Early in the pandemic, it became obvious that old and frail people with multimorbidity had the highest risk of severe disease course and death of COVID- $19 ;^{2-4}$ by September 2020, 58\% of reported deaths of COVID-19 in Norway occurred in nursing homes. ${ }^{5}$ Consequently, the most comprehensive social distancing measures were implemented for old adults living in nursing homes. Nursing home residents were urged to protect themselves by social distancing to a greater extent than the rest of the population. ${ }^{6}$ An
Correspondence: Signe Tretteteig Tel +4790108938

Email signe.tretteteig@aldringoghelse.no (c) $\odot 2022$ Tretteteig et al. This work is published and licensed by Dove Medical Press Limited. The full terms of this license are available at https://www.dovepress.com/ (c) ${ }_{\mathrm{BY}} \mathrm{NC}$ terms.php and incorporate the Creative Commons Attribution - Non Commercial (unported, v3.0) License (http://creativecommons.org/licenses/by-nc/3.01). By accessing the work you hereby accept the Terms. Non-commercial uses of the work are permitted without any further permission from Dove Medical Press Limited, provided the work is properly attributed. For permission for commercial use of this work, please see paragraphs 4.2 and 5 of our Terms (https://www.dovepress.com/terms.php). 
American study reported that daily in-person contact with other people decreased in $88 \%$ of older adults after COVID-19. ${ }^{7}$ In the early phase, Norwegian nursing homes were totally closed to visitors, and while most nursing homes opened up for visitors after some months, visits have been permanently regulated and limited. ${ }^{1}$ McArthur et al (2021) found that among Canadian nursing home residents, the number who had in-person visits with family decreased from $73.2 \%$ before lockdowns to $17.9 \%$ during lockdowns. ${ }^{8}$

The restrictions have been challenging for the residents, their relatives, and care staff, and they have given rise to difficult choices and caused great suffering for many people. Several articles in Norwegian newspapers, posts in social media as well as a national report developed by the Norwegian Centre for Care Research, have described the impact on relatives as devastating with a profound experience of loss and guilt. The visit regulations have been strict with limited flexibility. Relatives were worried about the residents need for social contact and activities of daily living. It has been especially difficult related to residents with dementia not being able to understand the situation or making use of phone, video communication or social media. ${ }^{9-12}$

When a person moves into a long-term nursing home, family members and friends usually continue to be involved in their care and provide significant support. ${ }^{13}$ Knowledge about the general experience of relatives of people living in long-term care is sparse. ${ }^{14}$ Several studies have highlighted the importance of contact and emotional support from families upon resident admission. ${ }^{15,16}$ Other issues, such as inadequate resident personal care, lack of communication with long-term care physicians, and challenges of surrogate decision-making, could lead to stress among relatives of residents in long-term. ${ }^{16}$ Nåden et al (2013) revealed varieties of indignity in the care of longterm care residents, as experienced by family caregivers. ${ }^{17}$ Hertzberg and Ekman (2000) stated that relatives' and care staff's experiences with each other are related to issues of influence, participation, trust, and measures to avoid conflicts. $^{18}$ Other issues that have been well-studied are end-of-life care and shared decision-making in end-of-life questions for long-term care residents ${ }^{19}$ and long-term dementia care. $^{20}$

Before COVID-19, more than $50 \%$ of family caregivers monitored, managed care, and assisted with meals, and several assisted with personal care tasks. Other roles for the relatives include advocating for the resident and maintaining the resident's stability and connectivity with other family members and friends. ${ }^{21}$ Powell et al (2018) found that relatives were involved in timely detection of changes in health in residents, by noticing changes in health, informing and educating care staff about the health changes in their family member. ${ }^{13}$ Thus, visits from relatives are very important to the resident's overall health. ${ }^{22}$ In addition, frequent communication between relatives and nursing home care staff are found to improve residents' quality of life. ${ }^{23}$ Some studies have investigated the effect of physical distancing and social isolation on mental health in the general population of old adults during the pandemic. Krendl and Perry (2020) found a higher level of depression and loneliness in old adults following COVID19 compared with prior to the pandemic, with the experience of loneliness predicting depression. ${ }^{24}$ In contrast, McArthur (2021) stated that the proportion of nursing home residents with indications of depression decreased from nearly $20 \%$ before to $11.5 \%$ during lockdown. ${ }^{8,25}$ This study has shown that more frequent contact by phone was associated with fewer negative emotions among residents in long-term care. Greater email frequency was also associated with more perceived positive emotions in residents, while letters delivered by care staff and the postal service were associated with more perceived resident negative emotions among residents.

\section{The Perspective of Self-Determination}

Theories about human motivation and need of support for relatives in a situation with challenging choices, might be useful to explore and understand the impact of the COVID-19 pandemic on these phenomena. SelfDetermination Theory (SDT) is an approach to human motivation and personality that is based on the theory of goal-directed behavior, which posits that human behavior is driven by initiative, actions, and goals. ${ }^{26,27}$ The SDT highlights the importance of humans evolved inner resources for personality development and behavioral self-regulation. Care staff having the skills to facilitate a safe and confident dialogue could be crucial to relatives becoming aware of their motivations and goals. Human behavior often consists of both intrinsically and extrinsically motivated actions, but if the action is based more on intrinsic than extrinsic motivation, it may have some positive consequences. Furthermore, if goals and actions are driven by intrinsic motivation, this makes the person more creative in terms of finding solutions and more cognitively 
flexible in problem-solving, which makes them more receptive to learning new things. ${ }^{26}$

To our knowledge, no studies have investigated the experiences of the COVID-19 pandemic of relatives of residents in nursing homes who were infected and how the physical distancing might have influenced relatives. Therefore, the aim of this is study was to explore these experiences by answering the following two research question: How did relatives of COVID-19 patients in Norwegian nursing homes experience the situation, and how did the physical distancing and precepts of infection control affect the relationship between the long-term residents and the relatives?

\section{Materials and Methods}

The study has a qualitative explorative design, and it uses individual in-depth interviews to collect data. Participants were invited to talk about their experiences of being the relative of a nursing home resident with COVID-19. Individual interviews were considered an appropriate method to obtain in-depth knowledge of the relatives' individual experiences.

\section{Sample and Requirements}

The participants were recruited by local gatekeepers such as dementia coordinators and nursing home leaders, from the network of the Norwegian National Advisory Unit on Ageing and Health. The gatekeepers distributed written and oral information on the study to family caregivers of nursing home residents infected by COVID-19, which included an invitation to take part in the study. Contact information for the research group was also included, making it possible to sign up for participation. Inclusion criteria were being a relative of a nursing home resident with COVID-19; caregivers with infrequent contact with the resident, defined as less than twice a month, were excluded. Some residents had survived the disease and recovered from COVID-19, while others had died. The sample consisted of ten participants, from seven different nursing homes (one spouse, eight adult children, and one grandchild), eight women and two men, aged 27-67 years. The included participants lived in both urban and rural areas, in small, medium, and large municipalities.

\section{Data Collection}

The interviews were conducted in line with a phenomenological-hermeneutic approach. The participants were encouraged to share their experiences and to describe how they felt during the period of sickness and, for some, death of their nursing home resident relative. The interviews took place between December 2020 and February 2021 via telephone and were audio-recorded and then transcribed verbatim. They had a dialogical form based on a semi-structured thematic interview guide (see Table 1).

Table I Interview Guide

\begin{tabular}{|c|c|}
\hline \multicolumn{2}{|l|}{ Interview Guide } \\
\hline Theme & Questions \\
\hline Introduction & $\begin{array}{l}\text { Can you tell me about how you experienced being a relative of NN when she/he was ill with corona?/Was ill and } \\
\text { died of corona? }\end{array}$ \\
\hline Isolation/visit regulations & $\begin{array}{l}\text { How did you keep in touch with NN when she/he was ill? } \\
\text { How did you feel about that? }\end{array}$ \\
\hline $\begin{array}{l}\text { Prioritization/treatment } \\
\text { clarification }\end{array}$ & $\begin{array}{l}\text { Were you involved in/informed about what treatment NN should receive for corona?/Did you have a treatment } \\
\text { clarification interview?/How did you experience the treatment clarification? }\end{array}$ \\
\hline Terminal phase & $\begin{array}{l}\text { Then NN became seriously ill with corona. How did you experience this period?/How did you experience NN } \\
\text { dying under such circumstances? }\end{array}$ \\
\hline $\begin{array}{l}\text { Health professionals' care and } \\
\text { competence }\end{array}$ & $\begin{array}{l}\text { How did you experience } \mathrm{NN} \text { being taken care of by the health professionals at the nursing home? } \\
\text { Did you feel confident that NN received good treatment and care? } \\
\text { Did you get enough information? }\end{array}$ \\
\hline $\begin{array}{l}\text { The family's handling of the } \\
\text { situation }\end{array}$ & How has this time been for you as a family? \\
\hline
\end{tabular}




\section{Analysis}

The transcribed interviews were analyzed according to the qualitative content analysis inspired by Graneheim and Lundman (2004). ${ }^{28}$ The analysis was conducted in six steps. First, all transcripts were read to provide a sense of the whole, and themes considered suitable for answering the research question were identified. Second, meaning units in the text were identified. Third, the meaning units were condensed into descriptions that were close to the text, with the intention of keeping the subjective perspective of the participants. Fourth, the meaning units were extracted and labeled with codes. Fifth, the codes were compared based on similarities and differences and then grouped into subcategories. Sixth, the subcategories were grouped and abstracted as categories. ${ }^{28}$ NVIVO.11 was used in the first four steps of the analysis (QSR International, 2020). The first author (ST) conducted the initial analysis, following steps one through four; all authors took part in steps five and six. Examples from the analysis process are shown in Tables 2 and 3.

\section{Ethical Considerations}

The project was approved by the Norwegian Centre for Research Data (NSD), project number 503,268 and conducted in accordance with the Declaration of Helsinki. Based on written and oral information, the participants gave written informed consent. Names and other identifying characteristics were not recorded during the interviews, with the exception of gender, age and living conditions. Participants were encouraged to not give information during the interviews that could identify their family member; if mentioned in the interviews, such information was anonymized during the transcription. In this way, participants' anonymity was secured in the analysis and publication processes.

\section{Results}

The analysis revealed a diversity of caregiver experiences of symptoms, courses, and outcomes for the residents with COVID-19. Five of the participants' relatives recovered from COVID-19, while five lost their loved ones to the disease. Of those who recovered, the symptoms varied from mild to severe: some experienced a fluctuating, serious course of illness, leading to say a final goodbye several times, while other residents had stable and mild symptoms. Furthermore, for those who died, the symptoms and development of the condition varied: for some, it took

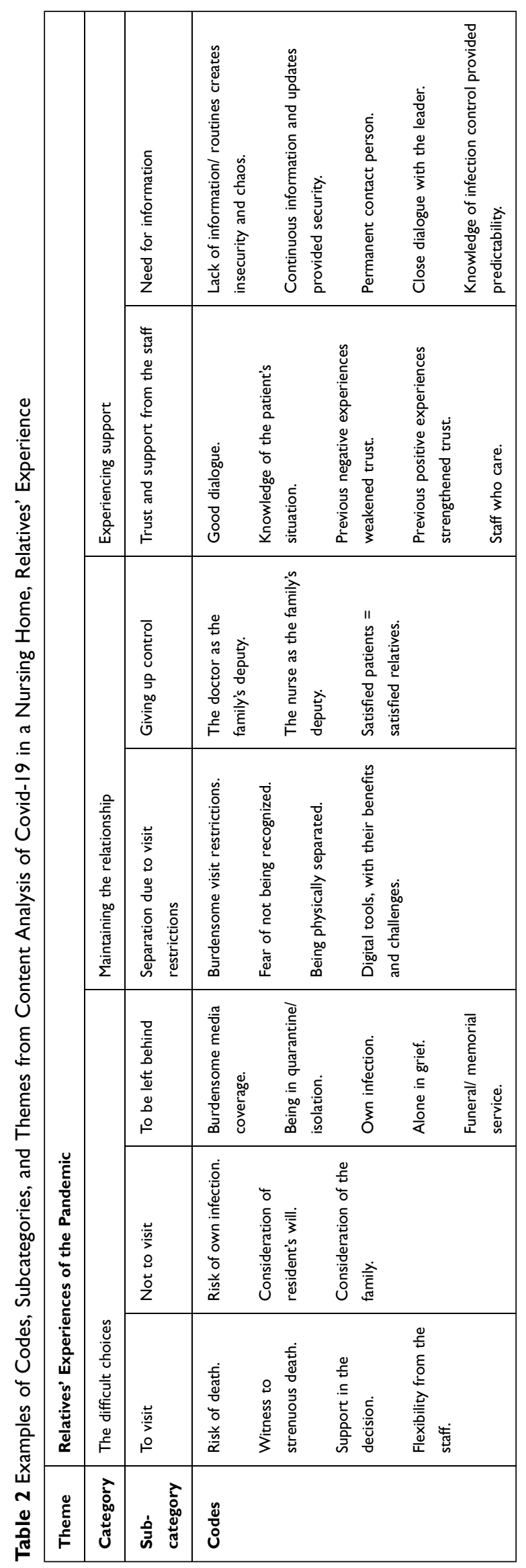


Table 3 Examples of the Analysis Process from Meaning Unit to Theme in the Content Analysis of Relatives' Difficult Choices

\begin{tabular}{|c|c|c|c|c|}
\hline Meaning Unit & $\begin{array}{l}\text { Condensed Meaning Unit. } \\
\text { Description Close to the Text. }\end{array}$ & $\begin{array}{l}\text { Condensed Meaning } \\
\text { Unit. Interpretation } \\
\text { of the Underlying } \\
\text { Meaning. }\end{array}$ & Subtheme & Theme \\
\hline $\begin{array}{l}\text { There was a lot of uncertainty around this. It } \\
\text { was that feeling of going in, I was very scared } \\
\text { that Dad would not understand that it was } \\
\text { me (...) Will he understand that it is me? }\end{array}$ & $\begin{array}{l}\text { Difficult to decide whether to visit or } \\
\text { not. Would he recognize me? It was a } \\
\text { difficult decision. }\end{array}$ & $\begin{array}{l}\text { Were visits worth the } \\
\text { risk of infection if her } \\
\text { father did not } \\
\text { recognize her? }\end{array}$ & \multirow[t]{4}{*}{$\begin{array}{l}\text { Separation } \\
\text { through } \\
\text { visit } \\
\text { restrictions }\end{array}$} & \multirow[t]{6}{*}{$\begin{array}{l}\text { Relatives' } \\
\text { experience } \\
\text { of the } \\
\text { pandemic }\end{array}$} \\
\hline $\begin{array}{l}\text { We tried Skype once }(. . .) \text { but he did not } \\
\text { understand anything. He saw us, but we were } \\
\text { not there, so he thought we were on TV. }\end{array}$ & $\begin{array}{l}\text { We tried to keep communicating via } \\
\text { Skype, but it did not work so well, the } \\
\text { technology is unfamiliar. }\end{array}$ & $\begin{array}{l}\text { Communicating } \\
\text { through technology } \\
\text { works poorly. }\end{array}$ & & \\
\hline $\begin{array}{l}\text { I notice that the months of contact } \\
\text { restrictions started to do something with } \\
\text { him. Especially not being able to give a hug, } \\
\text { because he was very into hugs. So, every } \\
\text { time we came, he said, "Is it allowed to hug?" } \\
\text { But no. "Oh, this is so sad," he said. }\end{array}$ & $\begin{array}{l}\text { It was hard for Dad that he could not hug } \\
\text { us. }\end{array}$ & $\begin{array}{l}\text { Less physical closeness } \\
\text { was emotionally } \\
\text { burdensome. }\end{array}$ & & \\
\hline $\begin{array}{l}\text { It hurts a lot when you cannot be there. And } \\
\text { the worst time, I think, was before he got } \\
\text { sick and we could not come and see or } \\
\text { follow up, due to the national visit } \\
\text { restrictions. }\end{array}$ & $\begin{array}{l}\text { The worst was really before he got sick, } \\
\text { because then we were not allowed to } \\
\text { visit him. }\end{array}$ & $\begin{array}{l}\text { Visit restrictions are } \\
\text { perceived as intrusive } \\
\text { to relatives. }\end{array}$ & & \\
\hline $\begin{array}{l}\text { They are so kind to mom, and if mom is } \\
\text { happy, then it's okay, then I am happy. Then I } \\
\text { am reassured. }\end{array}$ & $\begin{array}{l}\text { Mom is happy, and I have seen that they } \\
\text { are kind to her. Then I am satisfied. }\end{array}$ & $\begin{array}{l}\text { When the patient is } \\
\text { satisfied, relatives are } \\
\text { satisfied and relaxed. }\end{array}$ & \multirow[t]{2}{*}{$\begin{array}{l}\text { Giving up } \\
\text { control (to } \\
\text { staff) }\end{array}$} & \\
\hline $\begin{array}{l}\text { I felt the doctor became our extended arm. } \\
\text { She spent a lot of time with us and I really } \\
\text { appreciated that. She said: "Whatever you } \\
\text { decide to do, there is nothing right or wrong. } \\
\text { There is no one here who judges and walks } \\
\text { around and says, "Here, no relatives can } \\
\text { come."' }\end{array}$ & $\begin{array}{l}\text { The doctor became our extended arm } \\
\text { when we chose not to visit Dad. She } \\
\text { supported us in our decision, which was } \\
\text { very important. }\end{array}$ & $\begin{array}{l}\text { The doctor became } \\
\text { relatives extended arm. }\end{array}$ & & \\
\hline
\end{tabular}

less than a week (five to seven days) from the positive corona test until the resident's death, while others had more time together (up to two weeks) before the death occurred. Three main perspectives were identified from the participants' experiences and will be presented as the results: (1) the difficult choices; (2) maintaining the relationship; and (3) experiencing support.

\section{The Difficult Choices}

During the pandemic, caregivers had to adhere to both national and local restrictions around nursing home visits. For long periods, the nursing homes were closed to visitors, although they allowed visits in special cases. Thus, caregivers could visit under strict infection control restrictions when their loved one became seriously ill. This meant they had to choose whether they wanted to take the risk involved in visiting their loved one.

Both those who took the risk and those who did not, used a reflective, conscious approach to making their decision. A supportive professional caregiver discussing the different consequences of their options was highlighted as particularly important in this situation. One participant explained:

She [the doctor] spent a lot of time with us, and I really appreciated that she said, "Whatever you decide to do, there is nothing right or wrong."

The participants who decided not to visit the resident described this decision as very difficult, and the support 
from the physician and the nurses at the nursing homes who took the time to listen and offer supervision was essential. The opinions of other family members and the potential wishes of the resident, in cases where they had been capable of giving their opinions, were also considered in their decision-making process.

In considerations of whether to visit the resident, relatives emphasized the risk of spreading the virus to others if they themselves were infected. The risk of quarantine or getting sick could have consequences for their ability to work or to be together with other people who were important to them. One participant shared:

I have a lot of grandchildren around me, and it is important for me to meet them, so I would rather not risk bringing the virus with me. I need to be with these little kiddos, they are my "vitamin pills" as I used to tell them.

Some of those participants who chose to be with the resident at their deathbed felt that they had no choice: the thought of their loved ones dying without being there was unimaginable, even if they risked being infected with COVID-19. Those who chose to visit experienced a high level of support from the care staff, who facilitated their visits and cared for them while being at the resident's bedside. One participant described:

The nursing staff has been outstanding. No doubt the situation was a huge challenge for them too, the fact that we were there. But they were incredibly positive and helpful and did all they could to make it possible to visit him.

Several of the relatives were infected during visits, and this had serious consequences for the processes of grief and funerals. In families infected by the virus, many of the family members were in quarantine or isolation after the resident's death. This was a painful experience in a situation where families needed to be with each other in their grief. One participant explained:

Usually, the family becomes closer to each other in such circumstances, but we were not able to. (...) The opportunity for mutual support and comfort was unavailable. Other members of the family were in quarantine, and I was isolated on my own. It was mentally hard.

For some families, it was a challenge to arrange the funeral in line with the restrictions on how many people could be gathered, or because family members were sick, in quarantine, or in isolation. Some participants felt that they were unable to say a proper goodbye to the person who died.

\section{Maintaining the Relationship}

The restrictions on visits were adjusted in response to the local spread of the virus and thus could vary from one week to the next. The visit restrictions had a serious impact on the relationship between the participants and the residents. In some periods, visits were allowed, but touching or hugging the resident was advised against. This was also described as difficult:

I notice that the months of contact restrictions started to do something to him. Especially not being able to give a hug, because he was very into hugs. So, every time we came, he said, "Is it allowed to hug?" But no. "Oh! this is so sad," he said.

In the absence of visits, different digital communication technologies were tried - to varying degrees of success, as told by one participant:

We tried Skype once (...) but he did not understand anything. He saw us, but we were not there, so he thought we were on TV.

Cognitive impairment and dementia made it difficult to use digital technologies for communication; even talking on the telephone could be challenging, due to sensory dysfunctions. Two participants talked about their loved ones not being able to handle the phone on their own because of reduced vision: they were dependent on help from care staff to use their mobile phones. Another participant was thrilled by her mother being able to communicate by a digital technology with a screen, making it possible to see, hear, and speak with her family. This provided a large extent of assurance for the family.

When family were unable to visit and no longer had control of the situation, their experiences of how the care staff took care of the resident were very important. If the communication and trust were good, the care staff could act as the caregivers' "extended arm", such as by handing over personal notes and greetings. In cases of mistrust and insufficient communication with care staff, participants were worried and unsecure about the resident's situation.

I asked if my spouse had gotten out of bed today, but she did not know (...) I want you to call me as soon as possible, because I am concerned about him, so I do not have to worry. (...) It took half an hour, but no one called, so I had to call again.

A lack of communication could result in repeated phone calls from relatives to the resident, then to the care staff to share information, and then again to the resident to check if the care staff had been there to offer 
help. Trying to retain control of the situation in this way was described as exhausting.

\section{Experiencing Support}

The care staff taking time to inform and support the relatives was highly appreciated, and it was crucial to enhance the feeling of safety and trust, as explained by one participant:

The fact that they updated us continuously about his condition (...) and that she [the physician] spent a lot of time (...) I thought, if she spends so much time on me, I guess she also takes good care of my father.

The availability to reach the care staff by phone, and the fact that they were highly competent in infection control, made the participants feel safe. Furthermore, the care staff's in-depth knowledge about the resident, their compassion, and their care of the resident were highly appreciated by the caregivers. One of them said:

When I called the nursing home, the care staff answered in a professional and good way. The nurse who called me when he had died was crying on one end and I was crying on the other end. I felt safe that somebody had held his hand while he was dying. When I was not able to be there, somebody who really cared had been there with him. He was not alone.

In cases where the participants had good experiences with the nursing home (including confidence in the care staff's skills) before the pandemic, this was reinforced in the new and stressful situation, as illustrated in the following quote:

Yes, we felt confident in the quality of care, and it has grown even better. We are impressed with how they handled the situation and positively surprised about how they manged this crisis. I guess they have good leadership.

In cases where the participants had previous negative experiences and limited trust in the quality of the nursing home, the pandemic enhanced the caregiver's worries and feelings of unsafety. The participants felt they had to look after the resident to ensure that they got the treatment and care they needed. One of them said:

If you have a bad experience, this gets even more apparent during the pandemic. Many strange things happened earlier as well. I think it is very unprofessional (...) I am his advocate, you know, so I must bring up questions.

Some participants experienced a lack of support due to the leadership and care staff being inadequately prepared and lacking equipment to prevent the spread of the virus at the nursing home. A lack of routines for information sharing and uncertainty about infection control were also observed. This was stressful for the caregivers, as they did not know how to relate to the restrictions or how the residents were cared for. After a while, routines were established, and the participants could use less energy to acquire the information they needed, and they subsequently calm down.

\section{Discussion}

The participants' need for information, communication, and support is a repeated central message in all perspectives identified in the findings of this study. To meet health care professionals who are competent in infection control and who have updated knowledge about the resident's situation is crucial. Furthermore, the skills to facilitate a safe and confident dialogue is essential for the participants' feeling of safety in a stressful situation with difficult choices to make. The findings reveal significant experiences shared by the participants, illuminating the consequences of satisfactory versus insufficient information, communication, and support.

\section{Finding the Goal and Intrinsic Motivation}

The deadly pandemic led to complex and difficult choices for the relatives in this study. For instance, they had to consider the risk of visiting their COVID-19-infected parent, grandparent, or spouse versus the relational negative consequences of not visiting. For a deeper understanding of the importance of care staff's supporting relatives, the SDT meaning of instinct motivation, may be useful. ${ }^{26,27}$

In terms of setting goals that are driven by a person's intrinsic motivation and making the necessary choices and carrying out the necessary actions that lead to these goals, three universal inherent psychological needs influence us. According to SDT, these three needs are: 1) the experience of possessing the competence to achieve the goal (knowing which actions are appropriate); 2) the experience of a relational affiliation to the person(s) who guides or helps us (receiving support from a warm and caring person); and 3) the experience of autonomy in the situation. In cases where the care staff spent time talking and listening to the relatives and were competent in infection control and updated in their knowledge about the resident's situation, relatives were guided to making choices in the line with their intrinsic motivations, and they experienced autonomy in the situation, according to SDT. In contrast, relatives who experienced that the care staff lacked competence, updated knowledge about the resident's situation, and the 
skills to facilitate a safe and confident dialogue became frustrated and stressed. SDT explains that nonoptimal challenges and lack of connectedness disrupt the inherent actualizing and organizational tendencies endowed by nature; thus, such factors result not only in the lack of initiative and responsibility, but also in distress and psychopathology. $^{26}$

\section{The Need for an Extended Arm}

Caregivers' trust and confidence were a prerequisite for taking this role of caregivers' "extended arm". When caregivers are not able to be present themselves, it was of utmost importance that they could trust the care staff's capacity to take good care of the resident. This trust was established by the care staff consistently offering information, answering questions, and listening actively to the caregivers' input and wishes. Previous research has underlined that nursing home care staff cannot replace the social support and care from family caregivers during the pandemic. ${ }^{29}$ For the residents to feel dignity and love, contact with their relatives is important. Close contact with family and friends can prevent residents feeling forgotten and banished. ${ }^{15}$ The findings in the current study reveal that in cases where the health care professionals called the caregivers regularly, sent SMS greetings, and assisted with communication technology, they contributed to maintaining participants' caregiver role. According to Caspari, ${ }^{15}$ this contact may contribute to the residents' feelings of dignity, love, and inclusion in a situation of isolation and dearth of family visitors.

Nursing homes with routines of steady streams of information and updates on the resident's condition markedly boosted the caregivers' confidence and enhanced their trust in the professionals' capability to take good care of the resident. The challenges of reaching the resident by phone or digital platforms extended the care staff's responsibility to communication between caregiver and resident in the periods of restrictions on visits. Similar challenges in the COVID-19 pandemic were described in a Canadian study, where residents lacked access to internet and digital technologies during the pandemic, which severely hindered the residents to be in contact with relatives during the period of visit restrictions. The author pointed out an inherent bias of assuming that the aging population is passive and lacks the ability to learn, combined with the fact that this population does not advocate for itself because it is very often deprived of technological advances. $^{30}$
Approximately $84 \%$ of residents in long-term care in Norway have dementia. ${ }^{31}$ This condition not only affects the person with dementia but also has an impact on the person's family and friends, particularly the spouse. ${ }^{32}$ Dementia reduces the possibility to learn to use new technology, such as smart phones and tablets. Nevertheless, it must be considered whether this lack of capability to use technology devices could also be explained by little investment in support and aid for people with dementia; it could also be caused by poor consideration of the needs of the elderly in developing and implementing technologies. ${ }^{33}$ People with dementia can also have problems with understanding and remembering why their relatives do not visit them anymore; and as a consequence they are more vulnerable to depression and feelings of loneliness. ${ }^{24}$

\section{End of Life - the Need for an Open Dialogue}

When a resident is dying, updated knowledge about the resident's situation and the care staff's skills to facilitate a safe and confident dialogue became very important for the safety of the resident and the contact between the resident and the relatives. Our findings reveal that the choice to not be present at the time of death can be a painful decision involving a great deal of doubt. Open dialogue between health care professionals, relatives, and if possible, the resident can relieve the pain and decrease the caregivers' despair during the resident's terminal phase and death from COVID-19. These results are in line with findings from other studies, ${ }^{34}$ reporting on a medical centers highly affected by COVID-19. Effective remote communication with the resident and with the health care team was associated with significantly better family experiences of endof-life care. ${ }^{34}$ Feder et al (2021) investigated bereaved family members' perceptions of the quality of end-of-life communication during the COVID-19 pandemic, and they emphasized communication among residents, families, and healthcare teams as critically important during times of limited in-person visitation. Low-quality communication caused profound distress that could affect the quality of the terminal phase for the residents and the bereavement experiences in family members. ${ }^{35}$

After death, the relatives had to live with the consequences of their choices - both those who chose to visit and eventually became infected, and those who stayed at home and did not get the possibility to say goodbye. According to SDT, those who received support and 
information that helped them to act in line with their motivation and goals reconciled more easily with the consequences of the choices they made, and they avoided distress and psychopathology.

\section{Methodological Considerations}

This study included 10 participants sharing their personal experiences of being a relative to a COVID-19 patient in seven Norwegian nursing homes. They had various relationships to the COVID-19 patients. Some of them experienced that their loved one died, while others had relatives recovering from the disease. The sample is small with a heterogeneous composition and therefore the transferability is limited. However, the purpose of a qualitative study is not to generalize but rather to understand a phenomenon more in depth and possibly find essential structures and patterns that could guide practice and initiate future research to extend the knowledge.

\section{Conclusions}

The COVID-19 pandemic had reduced the relatives' communicate with and offer their care to seriously ill and dying residents with COVID-19 in nursing homes. The relatives experienced ethical dilemmas when weighing the risk of getting COVID-19 if they visited their love one versus the consequences of not visiting their loved one. In this situation, they needed good information and support from health care professionals. To enable the relatives to make choices in line with their goals and intrinsic motivations, it is important that the staff is competent in infection control, has updated knowledge about the resident's situation, and possesses the skills to facilitate a safe and confident dialogue. This is essential for relatives' trust in the care staff and their feeling of safety in a stressful situation involving difficult choices. Lack of confidence, routines, and dialogue might increase the relatives' feeling of unsafety and stress and make their caring role difficult. The wide variation in how caregivers experienced the care staff taking responsibility for information and communication reveals the need for clear guidelines for communication with caregivers and for facilitating communication between caregivers and residents when the possibility to visit is absent or restricted.

\section{Data Sharing Statement}

Requests for the dataset accompanied by an explanatory letter can be submitted to the first author.

\section{Consent for Publication}

All authors approved the final version of the manuscript.

\section{Acknowledgments}

The authors would like to thank all relatives who shared their experiences in this study.

\section{Author Contributions}

The study was initially designed by SE and AMMR. The interview guide was developed by the first author (ST), with input from all authors. ST conducted the interviews and was responsible for analyzing and interpreting the findings, with support from SE and AMMR. All authors made a significant contribution to the work reported, whether that is in the conception, study design, execution, acquisition of data, analysis and interpretation, or in all these areas; took part in drafting, revising or critically reviewing the article; gave final approval of the version to be published; have agreed on the journal to which the article has been submitted; and agree to be accountable for all aspects of the work.

\section{Funding}

The study was funded by the Norwegian National Advisory Unit on Ageing and Health, Vestfold Hospital Trust; Lovisenberg Diaconal University College; the Faculty of Health Sciences and Social Care, Molde University College; and the Research Centre for Agerelated Functional Decline and Disease, Innlandet Hospital Trust.

\section{Disclosure}

The authors report no conflicts of interest in this work.

\section{References}

1. The Norwegian government. News from Norwegian Ministries about the Coronavirus disease Covid-19; 2020. Available from: https://www. regjeringen.no/no/tema/Koronasituasjonen/tidslinje-koronaviruset/ id2692402/. Accessed April 20, 2021.

2. Hewitt J, Carter B, Vilches-Moraga A, et al. The effect of frailty on survival in patients with COVID-19 (COPE): a multicentre, European, observational cohort study. Lancet Public Health. 2020;5(20):3014630148. doi:10.1016/S2468-2667(20)30146-8

3. Myrstad M, Randoff AH. Akutt syke eldre i koronaens tid. Tidsskr nor Legeforen. 2020;140. doi:10.4045/tidsskr.20.0227

4. Ho FK, Petermann-Rocha F, Gray SR, et al. Is older age associated with COVID-19 mortality in the absence of other risk factors? General population cohort study of 470,034 participants. PLoS One. 2020;15 (11):e0241824. doi:10.1371/journal.pone.0241824

5. Folkehelseinstituttet. Dødsårsaksregisteret (Norwegian Death register). Available from: https://www.fhi.no/hn/helseregistre-og-registre/dodsar saksregisteret/forelopige-tall-for-covid-19-assosierte-dodsfall-i-dodsar saksregisteret/. Accessed April 20, 2021. 
6. Norwegian institute of Public health. Avstand, karantene og isolering [Distance, quarantine and isolation] Available from: https://www.fhi. no/nettpub/coronavirus/fakta/risikogrupper/. Accessed April 20, 2021.

7. Gaeta L, Brydges CR. Coronavirus-related anxiety, social isolation, and loneliness in older adults in northern california during the stay-athome order. J Aging Soc Policy. 2020;1:1-12.

8. McArthur C, Saari M, Heckman GA, et al. Evaluating the Effect of COVID-19. Pandemic Lockdown on Long-Term Care Residents' Mental Health: a Data-Driven Approach in New Brunswick. J Am Med Dir Assoc. 2021;22(1):187-192. doi:10.1016/j. jamda.2020.10.028

9. Jacobsen FF, Devik SA, Førland O, et al. Erfaringer med COVID-19 i norske sykehjem. 2021. Rapport 1/2021.

10. Alvestad PO, Kringstad K Koronautbrudd på sykehjem: Arnold (85) får ikke møte sine kjære i jula. NRK [Norwegian]. Available from: KoronasmittepåCharlottenlundhelse-ogvelferdssenter. Pårørendefårikketreffesinekjæreijula-NRKTrøndelag.

11. Solheim P Datteren får besøke Ella (90) en halvtime i uken: jeg er helt fortvilet. vg.no. Available from: https:/www.vg.no/nyheter/innen riks/i/VbWmMJ/datteren-faar-besoeke-ella-90-en-halvtime-i-ukenjeg-er-helt-fortvilet. Accessed April 14, 2020.

12. Myrvang SE, Bugge S, Sfrintzeris T Anbefalinger for sykehjemsbesøk endres - her treffer Liv (95) endelig igjen familien. NRK [Norwegian]. Available from: Anbefalingerforsykehjemsbesøkendres-hertrefferLiv (95)endeligigjenfamilien-VG.

13. Powell C, Blighe A, Froggatt K, et al. Family involvement in timely detection of changes in health of nursing homes residents: a qualitative exploratory study. J Clin Nurs. 2018;1-2:317-327. doi:10.1111/ jocn. 13906

14. Bergland A, Hestetun M. Samarbeid med pårørende i sykehjem. Sykepleien. 2003;91(18):42-45. doi:10.4220/sykepleiens.2003.0054

15. Caspari S, Lohne V, Rehnsfeldt AW, et al. Dignity and existential concerns among nursing home residents from the perspective of their relatives. Clin Nurs Stud. 2014;2(3):22-33. doi:10.5430/cns.v2n3p22

16. Givens J, Lopez RP, Mazor KM, Mitchell SL. Sources of stress for family members of nursing home residents with advanced dementia. Alzheimer Dis Assoc Disord. 2012;26(3):254-259. doi:10.1097/ WAD.0b013e31823899e4

17. Nåden $\mathrm{D}$, Rehnsfeldt $\mathrm{A}$, Råholm $\mathrm{MB}$, et al. Aspects of indignity in nursing home residences as experienced by family caregivers. Nurs Ethics. 2013;7:748-761. doi:10.1177/0969733012475253

18. Hertzberg A, Ekman SL. 'We, not them and us?' Views on the relationships and interactions between staff and relatives of older people permanently living in nursing homes. J Adv Nurs. 2000;3 (31):614-622. doi:10.1046/j.1365-2648.2000.01317

19. Gonella S, Basso I, De Marinis MG, Campagna S, Di Giulio P. Good end-of-life care in nursing home according to the family carers' perspective: a systematic review of qualitative findings. Palliat Med. 2019;6:589-606. doi:10.1177/0269216319840275

20. Nguyen M, Pachana NA, Beattie E, Fielding E, Ramis MA. Effectiveness of interventions to improve family-staff relationships in the care of people with dementia in residential aged care: a systematic review protocol. JBI Database System Rev Implement Rep. 2015;13(11):52-63. doi:10.11124/jbisrir-2015-2415

21. Williams SW, Zimmerman S, Williams CS. Family caregiver involvement for long-term care residents at the end of life. J Gerontol B Psychol Sci Soc Sci. 2012;67(5):595-604. doi:10.1093/geronb/ gbs065
22. Verloo H, Salina A, Fiorentino A, Cohen C. Factors influencing the quality of life perceptions of cognitively impaired older adults in a nursing home and their informal and professional caregivers: a mixed methods study. Clin Interv Aging. 2018;13:2135-2147. doi:10.2147/ CIA.S184329

23. Roberts AR, Isher K. Family Involvement in the Nursing Home and Perceived Resident Quality of Life. Gerontologist. 2018;58(6):10331043. doi:10.1093/geront/gnx108

24. Krendl A, Perry BL. The impact of sheltering-in-place during the COVID-19 pandemic on older adults' social and mental well-being. $J$ Gerontol B Psychol Sci Soc Sci. 2021;76(2):e53-e58. doi:10.1093/ geronb/gbaa110

25. Monin JK, Ali T, Syed S, et al. Family Communication in Long-Term Care During a Pandemic: lessons for Enhancing Emotional Experiences. Am J Geriatric Psychiatry. 2020;28(12):1299-1307. doi:10.1016/j.jagp.2020.09.008

26. Ryan RM, Deci EL. Overview of self-determination theory: an organismic dialectial perspective. In: Deci EL, Ryan RM, editors. Handbook of Self- Determination Research. The University of Rochester Press; 2002:3-33.

27. Ryan RM, Kuhl J, Deci EL. Nature and autonomy: an organizational view of social and neurobiological aspects ofself-regulation in behavior and development. Dev Psychopathol. 1997;9(4):701-728.

28. Graneheim UH, Lundman B. Qualitative content analysis in nursing research: concepts, procedures and measures to achieve trustworthiness. Nurse Educ Today. 2004;24(2):105-112. doi:10.1016/j. nedt.2003.10.001

29. Hado E, Friss Feinberg L. Amid the COVID-19 Pandemic, Meaningful Communication between Family Caregivers and Residents of Long-Term Care Facilities is Imperative. J Aging Soc Policy. 2020;32(4-5):410-415. doi:10.1080/08959420.2020.1765684

30. Eghtesadi M. Breaking Social Isolation Amidst COVID-19: a Viewpoint on Improving Access to Technology in Long-Term Care Facilities. J Am Geriatr Soc. 2020;68(5):949-950. doi:10.1111/ jgs. 16478

31. Helvik A, Engedal K, Benth JŠ, Selbæk G. Prevalence and Severity of Dementia in Nursing Home Residents. Dement Geriatr Cogn Disord. 2015;40(3-4):166-177. doi:10.1159/000433525

32. Livingston G, Huntley J, Sommerlad A, et al. Dementia prevention, intervention, and care: 2020 report of the Lancet Commission. Lancet. 2020;396(10248):413-446. doi:10.1016/S0140-6736(20)30367-6

33. Holthe T. Older Adults and Assistive Technology to Facilitate Occupation and Participation: A Complex Intervention Doktorgradsavhandling (Phd). Oslo Met; 2020.

34. Ersek M, Smith D, Griffin H, et al. End-Of-Life Care in the Time of COVID-19: communication Matters More Than Ever. J Pain Symptom Manage. 2021;62(2):213-222.e2. doi:10.1016/j. jpainsymman.2020.12.024

35. Feder S, Smith D, Griffin H, et al. "Why Couldn't I Go in To See Him?" Bereaved Families' Perceptions of End-of-Life Communication During COVID-19. J Am Geriatr Soc. 2021;69 (3):587-592. doi:10.1111/jgs.16993 


\section{Publish your work in this journal}

Nursing: Research and Reviews is an international, peer-reviewed, open access journal publishing original research, reports, reviews and commentaries on all aspects of nursing and patient care. These include patient education and counseling, ethics, management and organizational issues, diagnostics and prescribing, health outcomes, economics and resource management, improving patient safety in all settings. The manuscript management system is completely online and includes a very quick and fair peer-review system. Visit http://www. dovepress.com/testimonials.php to read real quotes from published authors. 